\title{
Occurrence and size distribution of silver nanoparticles in wastewater effluents from various treatment processes in Canada
}

\author{
Christian Gagnon $^{1}$ (D) P Patrice Turcotte ${ }^{1}$ • François Gagné ${ }^{1}$. Shirley Anne Smyth ${ }^{1}$
}

Received: 6 April 2021 / Accepted: 13 July 2021 / Published online: 29 July 2021

(C) Crown 2021

\begin{abstract}
The occurrence of silver (Ag) in urban effluents is partly associated with the increasing use of silver nanoparticles (Ag NPs) as an antiseptic agent in various consumer products. Distinction among $\mathrm{Ag}$ forms must be taken into account in the assessment of exposure and toxicological effects to aquatic organisms. Wastewater treatment processes effectively remove $\mathrm{Ag}$ particles and colloids (mostly $>95 \%$ ), but this still leaves notable concentrations (in order of $\mathrm{ng} / \mathrm{L}$ ) escaping to effluent-receiving waters. Total suspended Ag concentrations in various studied effluents ranged from 0.1 to $6 \mathrm{ng} / \mathrm{L}$. The purpose of this study was then to measure and characterize Ag NPs in urban effluents for their concentrations and size distribution using the single particle ICP-MS technique (SP-ICP-MS). Wastewater influents and effluents from various treatment plants—-from aerated lagoons to advanced treatment technology - were collected for three sampling days. Our results showed the presence of Ag NP in all samples with concentrations reaching $0.5 \mathrm{ng} / \mathrm{L}$ on a mass basis. However, on a particle number basis, Ag NP concentrations (expressed in particle $/ \mathrm{mL}$ ) in the 20-34-nm fraction (up to 3400 particles $/ \mathrm{mL}$ ) were much more abundant (> 700\%) than in the $>35$-nm larger fraction. The proportion of Ag at the nanoscale (1-100 nm) represents less than $8 \%$ of the total suspended $\mathrm{Ag}$ for all effluent samples, regardless of their origins. A significant correlation (linear regression: $r^{2}>0.7$ ) was observed between $\mathrm{Ag} \mathrm{NP}$ and total suspended Ag concentrations in investigated effluents. Because Ag nanotoxicity is size dependent, the determination of size distribution and exposure concentration on a particle number basis is urgently needed for risk assessment of this class of nanoparticles.
\end{abstract}

Keywords Ag $\cdot$ Silver nanoparticles $\cdot$ Single particle ICP-MS detection $\cdot$ Wastewater

\section{Introduction}

The presence of silver in urban effluents is associated with the increasing use of silver nanoparticles (Ag NPs) as an antiseptic agent (Musee et al. 2011; Dale et al. 2015). Indeed, Ag NPs are embedded in clothing, food containers, medical materials, and others (Bhatt and Tripathi 2011). The majority of Ag NPs in consumer products go down the drain and reach wastewater treatment plants (Kaegi et al. 2011). Although most wastewater treatment processes effectively (95\%)

Responsible Editor: Philippe Garrigues

Christian Gagnon

christian.gagnon@canada.ca

1 Science \& Technology Branch, Environment and Climate Change Canada, 7th Floor, St. Lawrence Centre, 105 McGill Street, Montreal, QC H2Y 2E7, Canada remove both particulate and dissolved $\mathrm{Ag}$, they still release notable concentrations (in order of few $\mathrm{ng} / \mathrm{L}$ ) to effluentreceiving waters ( $\mathrm{Li}$ et al. 2013).

The toxicity of Ag NPs on aquatic organisms could change markedly upon passing through municipal wastewater treatment plants (WWTPs), as their specific properties can be modified by physical and chemical transformations in WWTPs (Kaegi et al. 2011; Bruneau et al. 2016). Alterations of Ag NPs can be caused by a number of possible transformation processes such oxidation and sulphidation (Kaegi et al. 2011; Kraas et al. 2017; Lowry et al. 2012; Georgantzopoulou et al. 2018). When treated wastewater effluents are released in streams, they likely still contain $\mathrm{Ag}$ in dissolved, particulate, and NP forms. Dissolved ionic silver (Ag+) and small complexes are considered highly available Ag forms for aquatic organisms (Khan et al. 2012; Gagne et al. 2013).

From the environmental risk management perspective, it is important to better understand the size distribution of released $\mathrm{Ag}$ in nanoparticle forms since they could become more toxic 
than the bulk ion counterpart (i.e., $\operatorname{Ag}(\mathrm{I})$ because of the high surface area and reactivity (Bhatt and Tripathi 2011). Key physicochemical properties such as the particle size have been associated with the toxicity of engineered NPs (Jiang et al. 2009) where smaller nanoparticles tend to penetrate more quickly into cells, reaching the nucleus in some cases and producing more toxicity owing to increased surface-area-tovolume ratio. Cytotoxicity studies investigating the sizedependent cellular toxicity of Ag NPs also reported particle size-dependent cytotoxic effects and suggested careful consideration of particle size, not only concentrations, in testing design (Kim et al. 2012). Ag NPs have the potential to cause ecotoxicological effects due to both being within the nano size range and also from dissolution to Ag+ states (Jiang et al. 2009; Cunningham et al. 2013).

Their environmental monitoring, both in effluents and in their receiving aquatic ecosystems, requires a sensitive analytical approach that will allow the differentiation of the Ag NP from the dissolved Ag. Mass spectrometry coupled with argon plasma (ICP-MS) is commonly used for the analysis of total $\mathrm{Ag}$ at low levels (MDL $0.2 \mathrm{ng} / \mathrm{L}$ ). Recent technological advances of these instruments can also be used to distinguish between the nanoparticulate and dissolved Ag phases using the single particle detection approach (SP-ICP-MS). This technique involves collecting a series of measurements each millisecond for at least 1 min where dissolved and abundant elements evenly distributed in the solution generates a constant signal, while the passage of Ag NP in plasma produces short bursts $(0.5 \mathrm{~ms})$ of intense signal. The intensity of this signal is proportional to the size of the particle (Mitrano et al. 2012; Pace et al. 2011; Tuoriniemi et al. 2012). While such analytical approach is key for $\mathrm{Ag}$ speciation in surface waters, investigating Ag NP in complex wastewater samples remains a challenge. For a more accurate detection of Ag NP by SPICP-MS, the technique was modified by the use of $109 \mathrm{Ag}$ isotope detection avoiding zirconium oxides - generated by $\mathrm{Zr}$ particles - isobaric interferences in ICP plasma (Turcotte and Gagnon 2020).

A few studies have investigated the release of silver from municipal WWTPs based on particulate size distribution (e.g., Johnson et al. 2014; Li et al. 2016). Nanoscale Ag particles (defined as n-Ag-Ps) were specifically analysed by different size-based techniques, such as cloud point extraction (CPE), ion-exchange resin (IER), or ultrafiltration (UF) (Li et al. 2013; Gagnon 2018). The colloidal forms of n-Ag-Ps include forms such as $\mathrm{Ag}$ nanoparticles and $\mathrm{Ag}_{2} \mathrm{~S}$. While significant concentrations of detected $\mathrm{n}$-Ag-Ps can be seen as a sign of $\mathrm{Ag}$ NP occurrence in wastewaters ( $\mathrm{Li}$ et al. 2013; Johnson et al. 2014), more investigations of the $\mathrm{Ag}$ colloidal fraction are needed with better discrimination in the identification of $\mathrm{Ag}$ NP.

This is the first study on the characterization of NP Ag releases from different WWTPs using single particle-mode
ICP-MS, a technique adapted for the specific detection $(\mathrm{Ag}$ atoms based) of NPs (Turcotte and Gagnon 2020; Mitrano et al. 2012). The technique allows distinguishing Ag forms where each Ag particle, containing high Ag atom density, produces an intense peak, compared to other forms, in mass spectrometry. Various municipal WWTPs, using mechanical or biological treatments (activated sludge, nutrient removal) were sampled with the aim to determine their Ag removal and releases of different $\mathrm{Ag}$ forms, including particulate, colloidal, and nanoparticulate forms.

The objective of this investigation was therefore to examine the occurrence and the size distribution of $\mathrm{Ag}$ released from municipal effluents. Municipal effluents from ten municipalities using different treatment processes - from aerated lagoons to advanced biological treatments-were sampled across Canada. Moreover, untreated wastewaters were also collected to determine the overall Ag removal at WWTPs.

\section{Methods}

\section{Wastewater sampling collection}

Samples of wastewater raw influent and final effluent were collected from 10 WWTPs of different treatment technologies across Canada in 2017, targeting dry weather conditions periods as possible. Table 1 summarizes the various types of treatment of these WWTPs that included aerated lagoons (AL), secondary biological treatments using conventional activated sludge (ST), and two advanced biological nutrient removal treatments with tertiary filtration (AT). Both influent and effluent samples were collected for three consecutive days $(n=3)$ using Hach Sigma 900 refrigerated autosamplers (Hach Company, Loveland CO, USA) to obtain 24-h equal volume composite samples at $400 \mathrm{~mL}$ every $15 \mathrm{~min}$ and better consider effluent fluctuations. Wastewater samples were subsampled in 1-L high-density polyethylene bottles and shipped on ice to the laboratory. Subsamples of influent and effluent were transferred to $50-\mathrm{mL}$ polypropylene tube, and frozen at $-20^{\circ} \mathrm{C}$, without acid preservative solution, until the day of analysis. Samples were slowly thawed in a cold-water bath, in order to avoid over-heating of the samples, and then placed in an ultrasonic water bath for $5 \mathrm{~min}$ at $20^{\circ} \mathrm{C}$. For total Ag determination in influents and effluents, samples were acidified with $1 \% \mathrm{HNO} 3$ and $1 \% \mathrm{H} 2 \mathrm{O} 2$, in order to evaluate removal efficiency of the various wastewater treatment plants. Total suspended solids (TSS) were analysed by the Environment and Climate Change Canada's National Laboratory for Environmental Testing according to standard methods (APHA 2005) and removal efficiency for those quality-control parameters are summarized in Table 1. 
Table 1 Total Ag concentrations (ug/L) in wastewater influents and effluents from various treatment plants (WWTP) and removal efficiency. TSS: total suspended solids. *: values in parentheses are concentration variability for three sampling days

\begin{tabular}{|c|c|c|c|c|c|c|c|c|c|}
\hline $\begin{array}{l}\text { WWTP } \\
\text { type }\end{array}$ & Plant ID & $\begin{array}{l}\text { Flow } \\
\text { m3/day }\end{array}$ & Filtration & $\begin{array}{l}\% \text { TSS } \\
\text { removal }\end{array}$ & $\begin{array}{l}\text { Influent } \\
\text { Total Ag }\end{array}$ & & $\begin{array}{l}\text { Effluent } \\
\text { Total Ag }\end{array}$ & & $\%$ Ag removal \\
\hline \multirow[t]{2}{*}{ Aerated lagoon } & TB & 25,760 & None & 96 & 0.147 & $(0.013)^{*}$ & 0.025 & $(0.003)^{*}$ & 83 \\
\hline & $\mathrm{JL}$ & 27,650 & None & 92 & 0.074 & $(0.025)$ & 0.005 & $(0.001)$ & 93 \\
\hline \multirow{6}{*}{$\begin{array}{l}\text { Secondary } \\
\text { (Activated sludge) }\end{array}$} & SB & 1040 & Sand & 99 & 0.202 & $(0.099)$ & 0.002 & $(0.003)$ & 99 \\
\hline & WL & 37,890 & None & 98 & 0.254 & $(0.150)$ & 0.003 & $(0.001)$ & 99 \\
\hline & PD & 38,750 & None & 99 & 0.214 & $(0.190)$ & 0.002 & $(0.000)$ & 99 \\
\hline & HG & 2170 & Sand & 99 & 0.151 & $(0.099)$ & 0.005 & $(0.002)$ & 97 \\
\hline & PA & 3990 & None & 98 & 0.129 & $(0.045)$ & 0.003 & $(0.002)$ & 98 \\
\hline & PW & 35,100 & None & 99 & 0.292 & $(0.043)$ & 0.003 & $(0.001)$ & 99 \\
\hline \multirow{2}{*}{$\begin{array}{l}\text { Advanced with filtration } \\
\quad \text { (biological nutrient removal) }\end{array}$} & $\mathrm{E}$ & 35,770 & Cloth disc & 99 & 0.235 & $(0.010)$ & 0.009 & $(0.001)$ & 96 \\
\hline & $\mathrm{PN}$ & 11,720 & Cloth disc & 99 & 0.402 & $(0.423)$ & 0.008 & $(0.000)$ & 98 \\
\hline
\end{tabular}

\section{Total Ag analysis in wastewaters}

Mass spectrometry coupled with argon plasma (ICP-MS) was used for the analysis of total silver at low levels (LOD, $0.2 \mathrm{ng} /$ L). To assess Ag total concentration in solution, the instrument was calibrated with ion standards (SCP Science). The Ag ionic standard was purchased from SCP Science (Baied'Urfée, Montréal, Canada). By serial dilutions, solutions of $0.1,0.5$, and $1.0 \mu \mathrm{g} / \mathrm{L}$ were prepared in $1 \% \mathrm{HNO} 3$ (Baseline grade, SeaStar, Vancouver, Canada). The precision, expressed as coefficient of variation was $12 \%$ or better and detection accuracy, expressed as \% of recovery, was between 82 and $100 \%$.

\section{NP Ag analysis by SP-ICP-MS}

Ag NPs in urban effluents were evaluated by ICP-MS using the single particle technique (SP-ICP-MS) with a Thermo ${ }^{\mathrm{TM}}$ Model ICAP-RQ. Prior to analysis, the samples were transferred to $14-\mathrm{mL}$ polypropylene tubes and not filtered as we chose not remove particles in solution that could contain $\mathrm{Ag}$ $\mathrm{NP}$, but allowed partial sedimentation for $1 \mathrm{~h}$ of aggregates and large particles. With this procedure, the variation coefficient for total suspended Ag was better than $5 \%$ between sample duplicates. Because the main goal of this study was to evaluate the discharge of $\mathrm{Ag} \mathrm{NP}$, the $\mathrm{Ag}$ fraction evaluated was what remained in suspension. Thus, $\mathrm{Ag}$ nanoparticulate and dissolved phases were characterized on suspension samples using the single particle detection approach (SP-ICPMS). The analysis of Ag NP by the SP-ICP-MS technique makes it possible to measure the number and size of particles. The passage of Ag NP in plasma is characterized by an intense signal (peak) for a very short period of time $(0.5 \mathrm{~ms})$ while the signal of dissolved $\operatorname{Ag}(\mathrm{I})$ is evenly distributed as constant signal (Fig.1). The number of events is directly correlated with the number of nanoparticles in the solution and the pulse intensity is a function of the particle size which is related to the number of targeted isotopes (Degueldre et al. 2004; Mitrano et al. 2012; Pace et al. 2011; Tuoriniemi et al. 2012). For a more accurate detection of Ag NP in urban effluents by SPICP-MS, the technique was modified by the use of $109 \mathrm{Ag}$ isotope detection to avoid zirconium particle/colloid interferences. Zirconium is known to form oxides that interfere with the silver detection with 107 isotopes and to a lesser extent with 109. When $\mathrm{Zr}$ particles are present, the oxide interference signal is like Ag NP pulses (Turcotte and Gagnon 2020). The urban effluents contain zirconium particles and those induce false positives for small Ag NPs. We have defined a size threshold that included false positives probability of $20 \mathrm{~nm}$. Thus, particles with size below $20 \mathrm{~nm}$ were not considered as Ag NPs. The data processing was done with a Thermo ${ }^{\mathrm{TM}} \mathrm{NP}$ Quant software according to the equations defined by Pace et al. (2011). The acquisition time was $120 \mathrm{~s}$ and the dual time $2.5 \mathrm{~ms}$ allowing the integration of the entire signal peaks. The intensity for $1 \mu \mathrm{g} \mathrm{Ag} / \mathrm{L}$ was $185000 \mathrm{cps}$. The transport rate, as defined by Pace et al. (2011) and Mitrano et al. (2012), which relates the measured concentration (particle $/ \mathrm{mL}$ ) of Ag NP in the instrument to that of the sample, was approximately $7.5 \%$. This was evaluated with certified $80 \mathrm{~nm} \mathrm{Ag} \mathrm{NP}$ and $80 \mathrm{~nm} \mathrm{Au} \mathrm{NP}$ purchased from TED PELLA TM. The standards of $4.2 \mathrm{ng} / \mathrm{L}$ of NP-Ag- 80 and NP-Au-80 were prepared in a solution (Milli-Q water) of tri-sodium citrate $(2 \mathrm{mM})$. The SP-ICP-MS technique also makes it possible to quantify the total concentration of silver in solution, the dissolved phase (ionic and small complexes), and the size and number of Ag NP. The detection limit for dissolved silver was $0.1 \mathrm{ng} / \mathrm{L}$. The minimum number of Ag NP that can be detected was 15 particles $/ \mathrm{mL}$ of sample. This same minimum number of detection, expressed in ng of $\mathrm{Ag} \mathrm{NP} / \mathrm{L}$, when applied to only particles 


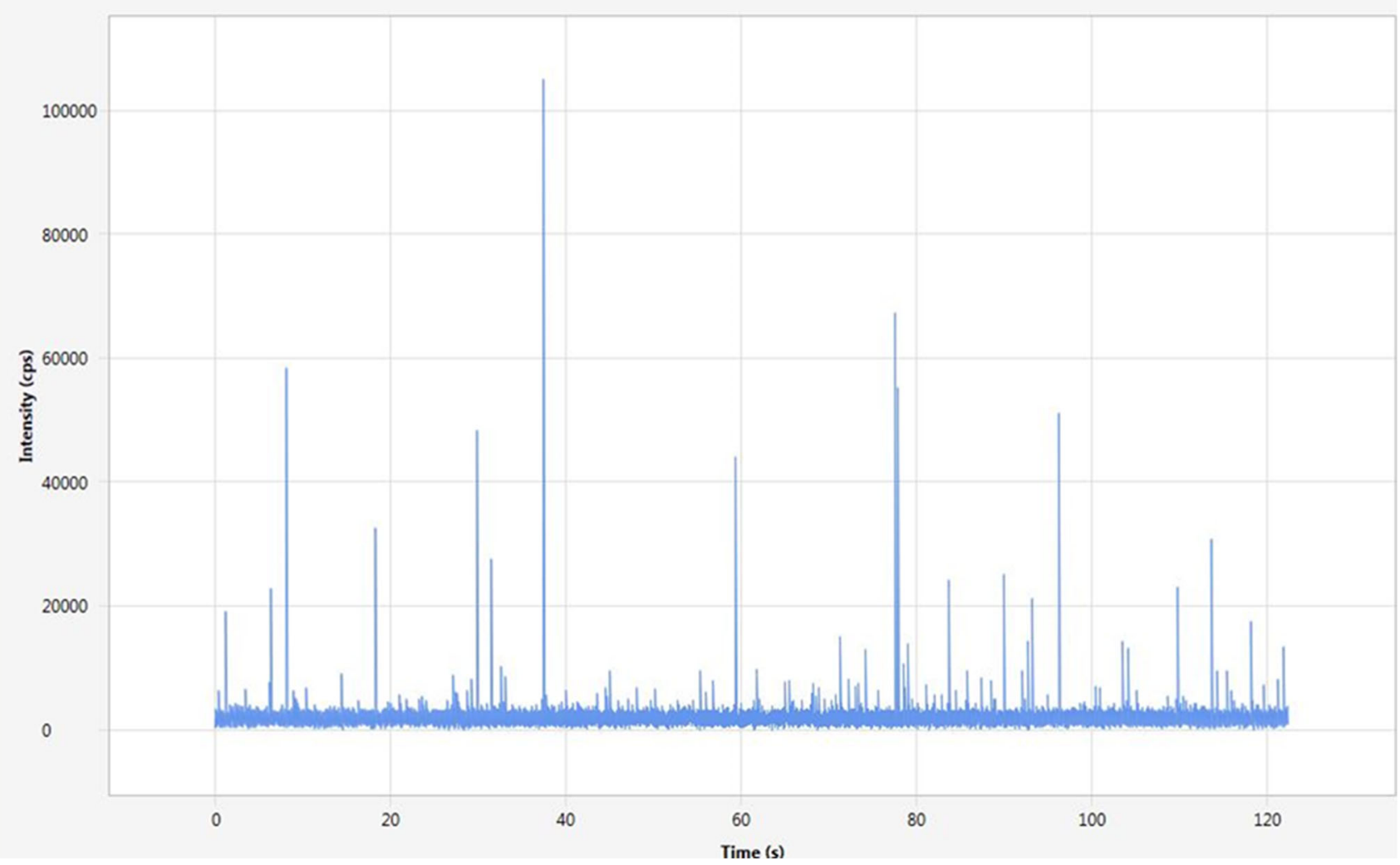

Figure 1 Example of analytical detection of silver (Ag NP and dissolved Ag) by single particle ICP-MS in municipal wastewater effluent samples

of $20 \mathrm{~nm}$, was equivalent to $0.0003 \mathrm{ng} / \mathrm{L}$. For the fraction of $\mathrm{Ag}$ NP 20-34 nm expressed in ng/L, RDS was better than $15 \%$ while expressed in part $/ \mathrm{mL}$ it was $18 \%$. For the fraction $>35 \mathrm{~nm}$, they were better than 49 and $44 \%$, respectively. The total suspended $\mathrm{Ag}$ concentration, $\mathrm{Ag}$ particle number, and ng/L concentration were all measured during the same analysis.

We operationally ranked our results in three classes: total suspended silver (without aggregates and large particles), NP $>35 \mathrm{~nm}$, and small Ag NP $=20-34 \mathrm{~nm}$. The summation of the two fractions of Ag NP in ng/L divided by total suspended silver allows estimating the proportion (\%) in mass of Ag NP in the sample analysed by SP-ICP-MS.

\section{Results and discussion}

\section{Silver removal at WWTPs}

Concentrations of total $\mathrm{Ag}$ ranged from 0.15 to $0.40 \mu \mathrm{g} / \mathrm{L}$ in influent samples (before treatment) and from 0.003 to 0.025 $\mu \mathrm{g} / \mathrm{L}$ in the treated effluent samples (Table 1). The highest total Ag concentrations $(0.025 \mu \mathrm{g} / \mathrm{L})$ reported for the studied effluents were observed in an aerated lagoon. Total Ag concentrations (Ag NP and $\mathrm{Ag}(\mathrm{I})$ ) were previously measured in effluent samples from a WWTP in California, USA, with high values ranging from 0.04 to $0.07 \mu \mathrm{g} / \mathrm{L}$ (Cervantes-Avilés et al. 2019). The authors reported removal of 76 and $96 \%$ of the colloidal Ag fraction by secondary and tertiary ultrafiltration treatment processes, respectively. In this study, the removal efficiencies were all above $80 \%$, often reaching $>96 \%$ (Table 1). As a result, concentrations of total $\mathrm{Ag}$ in treated wastewater effluents were relatively low with values lower than $25 \mathrm{ng} / \mathrm{L}[0.025 \mu \mathrm{g} / \mathrm{L}]$. Reported mean values for the removal of particulate Ag at various British WWTPs were around $98 \%$, and to a lesser extent, near $50 \%$ of removal for the colloidal forms, being defined here by ultra-filtration with 2-nm cut-off (Johnson et al. 2014). The silver particulate form is most effectively removed with the sludge settlement process. Such results indicate potential escape of certain nanosilver fractions from WWTPs (Johnson et al. 2014). Total Ag removal performance among the different types of WWTPs investigated (aerated lagoon, activated sludge with or without filtration, biological nutrient removal with filtration) were all high $(<80 \%)$ when compared to the corresponding non-treated raw wastewaters. Hence, total Ag removal is treatment invariant with little exception for aerated lagoons. Trends in Ag removal were similar to those of total suspended solids (TSS) removal with the lowest values also observed for aerated lagoons (Table 1). 


\section{Release of Ag nanoforms from WWTP effluents}

In the process of determining the presence of $\mathrm{Ag}$ at the nanoscale (including all colloidal forms), total suspended Ag was first measured by ICP-MS in effluent samples with concentrations ranging from 0.1 to $6.0 \mathrm{ng} / \mathrm{L}$ (Table 1). These first values agree well with the German study's mean value of $5 \mathrm{ng} / \mathrm{L}$ for nanoscale and colloidal Ag estimated by an extraction based on cloud point technique ( $\mathrm{Li}$ et al. 2013). Based on the single particle ICP-MS technique, the presence of Ag NP was observed in all effluent samples. Results were arbitrarily operationally ranked in three classes: total suspended silver, Ag NP 20-34 nm, and Ag NP > $35 \mathrm{~nm}$ expressed as particle number (part./mL) or concentration (ng/L) (Fig 2). When expressed in particle/mL concentration, Ag NP in the 20-34-nm fractions were much more abundant than in the $>35$-nm larger fraction. On the other hand, when concentrations of Ag NP are expressed in $\mathrm{ng} / \mathrm{L}$, this trend was not highly observed as particles in the 20-34-nm fraction are lighter (Fig. 2). Due to different particle mass, a $40-\mathrm{nm}$ spherical particle is 4 times heavier than a $25-\mathrm{nm}$ particle. The summation of the two fractions of Ag NP in $\mathrm{ng} / \mathrm{L}$ divided by total suspended silver allows estimation of the percentage in mass of Ag NP in the sample (Table 2, Fig. 2). Ag NP measured by SP-ICP-MS ranged from 0.02 to $0.47 \mathrm{ng} / \mathrm{L}$ representing $1.7-7.6 \%$ of total suspended Ag in effluents. In a study on British wastewater treatment plants, the mean concentration of colloidal $(2-450$ $\mathrm{nm})$ silver, which includes nanosilver, was reported to be 12 $\mathrm{ng} / \mathrm{L}$ in influents and $6 \mathrm{ng} / \mathrm{L}$ in effluents (Johnson et al. 2014). For comparison in the same samples, particulate silver $(>450$ $\mathrm{nm}$ ) was rather within the $\mu \mathrm{g} / \mathrm{L}$ concentration range with mean values of 3.3 and $0.08 \mu \mathrm{g} / \mathrm{L}$ for influents and effluents, respectively. The contribution of Ag NP would therefore represent less than $8 \%$ of the suspended Ag released in effluents (Table 2). The proportion of silver in "nanometric forms" expressed in mass was, on average, $4 \%$ for all effluent samples, regardless of the type of wastewater. The concentration of Ag NP expressed in mass increased in relation $\left(R^{2}=0.96\right)$ with total Ag concentration in effluents. The highest NP proportion values were observed in the aerated lagoon effluents (Table 2). These results may suggest that treatments by lagoons are less effective in removing $\mathrm{Ag} \mathrm{NP}$ from effluents. Hence, the size distribution of $\mathrm{Ag}$ could be influenced by treatment strategies, where aeration lagoons discharge higher proportion of Ag NP. In the same way, lower removal of total $\mathrm{Ag}$ was also observed for those treatments by lagoons (Table 1). Relationships (linear regression: $R^{2}>0.7$ ) were observed, at some extent, between Ag NP and total suspended $\mathrm{Ag}$ concentrations in wastewater effluents (Fig. 2). Similar trends were also noted when the concentration of Ag NP is expressed as particle number $/ \mathrm{mL}$ (Fig. 2). Implicitly, concentrations of both, small and larger size particle fractions, were directly proportional to total suspended Ag concentrations. All these trends seem indicate that $\mathrm{Ag}$ in effluents may have a common origin.

Biological and physical processes in the secondary treatment generally removed more than $75 \%$ of the colloidal Ag fraction (Cervantes-Avilés et al. 2019). A study using cloud point extraction (CPE) method as the detection technique reported that nanoscale Ag particles (n-Ag-Ps) concentrations, which included all colloidal forms, in the influent were as high as $<1500 \mathrm{ng} / \mathrm{L}$ and decreased $(\sim 35 \%)$ in concentrations after primary treatment (physical clarification), indicating that initial treatment steps contributes to the n-Ag-Ps removal ( $\mathrm{Li}$ et al. 2013). Afterward, further biological treatment (activated sludge) effectively removed those colloidal forms, which resulted in low concentration $(0.7-11.1 \mathrm{ng} / \mathrm{L})$ of $\mathrm{n}-\mathrm{Ag}-\mathrm{Ps}$ in the effluents. Using the CPE technique, Li et al. (2016) demonstrated that more than $96 \%$ of nanoscale Ag particles (Ag-b-NPs) from wastewater influent are removed through WWTPs. In a laboratory experiment with municipal wastewater, spiked $\mathrm{Ag}$ NP was mostly observed as transformed sulphidized forms (Kim et al. 2010). Nanoscale $\mathrm{Ag}_{2} \mathrm{~S}$ particles were identified in sewage sludge using high-resolution transmission electron microscopy. Based on transformation kinetics, sulphidation of Ag NP would likely occur at NP surface as a result of
Table 2 Mean Ag NP concentrations in wastewater effluents from various wastewater treatment plant types (WWTPs)

\begin{tabular}{lllll}
\hline WWTP type & Plant ID & Total suspended Ag (ng/L) & $\sum$ Ag NP (ng/L) & $\%$ as NP \\
\hline Aerated lagoon & TB & 6.129 & 0.468 & 7.6 \\
Secondary & JL & 1.284 & 0.084 & 6.6 \\
& SB & 0.104 & 0.005 & 4.8 \\
& WL & 0.585 & 0.027 & 4.6 \\
& PD & 0.208 & 0.007 & 3.4 \\
& HG & 2.940 & 0.052 & 1.8 \\
& PA & 0.635 & 0.023 & 3.6 \\
Advanced with filtration & PW & 0.842 & 0.031 & 3.7 \\
& E & 3.284 & 0.057 & 1.7 \\
& PN & 3.101 & 0.122 & 3.9 \\
\hline
\end{tabular}



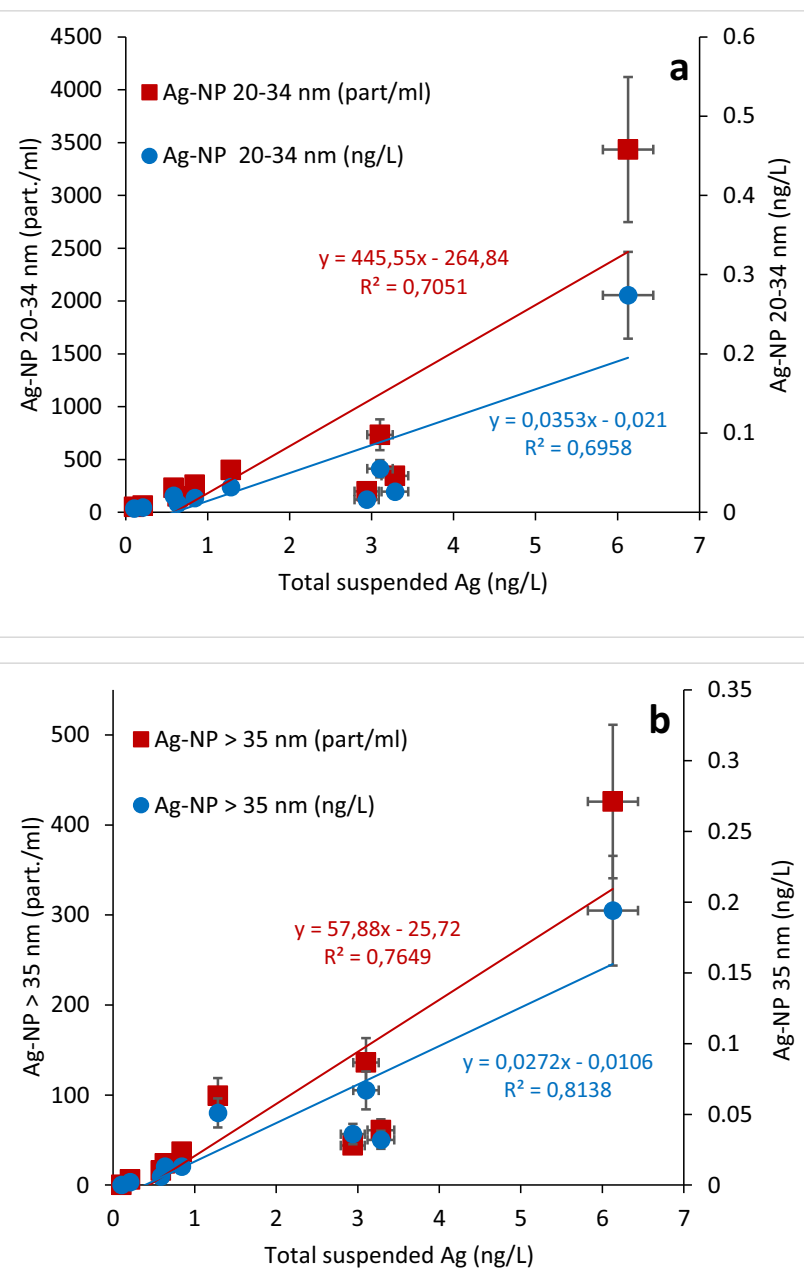

Figure 2 Distribution of Ag NP size fractions (20-34 and > $35 \mathrm{~nm}$ ) in wastewater. a). $\mathrm{Ag} \mathrm{Np} \mathrm{20-34-nm} \mathrm{fraction;} \mathrm{b} \mathrm{Ag} \mathrm{NP} \mathrm{>} \mathrm{35-nm} \mathrm{fraction}$

transformed Ag NP (He et al. 2019) which are also detected by SP-ICP-MS. The ultimate fate of most Ag material (up to 90\%) would be accumulated at the end of wastewater treatments in sludge as sulphides (Kaegi et al. 2011; Kim et al. 2010; Tiede et al. 2010; Thalmann et al. 2014).

Despite low concentrations of Ag escaping as NPs, such additional Ag sources - even in $\mathrm{ng} / \mathrm{L}$ concentration rangesfrom uses of nanotechnology and ultimately released in municipal wastewaters can be considered as cumulative contamination sources. These relatively low Ag concentrations are continually discharged at variable loads according to the size of the city and effluent flow. Even after high particulate and colloidal Ag removal efficiency ( $>95 \%$ ) by treatment plants, effluents were reported to release much lower concentrations of nanoscale $\mathrm{Ag}$ (up to $12 \mathrm{ng} / \mathrm{L}$ ), but still a relative $\mathrm{Ag}$ contribution to effluent-receiving surface waters ( $\mathrm{Li}$ et al. 2013; Johnson et al. 2014). As a result, colloidal Ag forms were tracked down along a major effluent dispersion plume (Gagnon et al. 2006), confirming the need for further physicochemical characterization. Because of the continuous release of $\mathrm{Ag}$ by municipal effluents, this represents an $\mathrm{Ag}$ source to aquatic environments where characterization of the size distribution of released Ag forms (Brar et al. 2010; Kaegi et al. 2013; Government of Canada 2016) down to the nanoscale is therefore needed for risk assessment.

A laboratory study carried out with river waters showed that Ag NP slowly degrades (half-life: 12 days) by releasing a little dissolved Ag(I) at a time (Gagnon 2018). Those experiments on transformation kinetics concluded that $\mathrm{Ag} \mathrm{NP}$ degraded into smaller NP and steadily released over time $\mathrm{Ag}+$ ion and small complexes as final degradation products under natural water conditions. Thus, measured $\mathrm{Ag}$ forms remaining in treated wastewater are likely the result, to some extent, of degradation processes and contribute to the overall $\mathrm{Ag}$ contamination of effluent-receiving waters. Following exposure to test media containing Ag NPs, silver ions ( $\mathrm{Ag}(\mathrm{I}))$ released from Ag NPs were typically targeted to be the major pathway leading to body burden (Kühr et al. 2018). No Ag ions, however, were significantly detected $(<0.1 \mathrm{ng} / \mathrm{L})$ in the dissolved phase of such complex matrices with abundant organic and inorganic $\mathrm{Ag}$ ligands. Nevertheless, all Ag NP forms and their transformation products - including complexed and adsorbed ion formscontribute to water contamination through the use of silvercontaining consumer products. Different studies have shown that ingested particulate $\mathrm{Ag}$ forms may also be bioavailable for aquatic organisms (Croteau et al. 2011; Gomes et al. 2013; Bruneau et al. 2016). For instance, with mussels, gills are the major organs for the uptake of dissolved $\mathrm{Ag}$, whereas Ag NP aggregates are primarily taken up by the gut or digestive gland. This points out the need to consider all NP aggregation and dissociation transformations that could influence exposure pathways and potential bioavailability.

While the observed concentrations in mass (ng/L) were within similar value ranges for small and large size fractions, more different values $(>700 \%)$ were obtained between the two fractions in terms of quantity of NP (particles $/ \mathrm{mL}$ ) (Fig. 3). Up

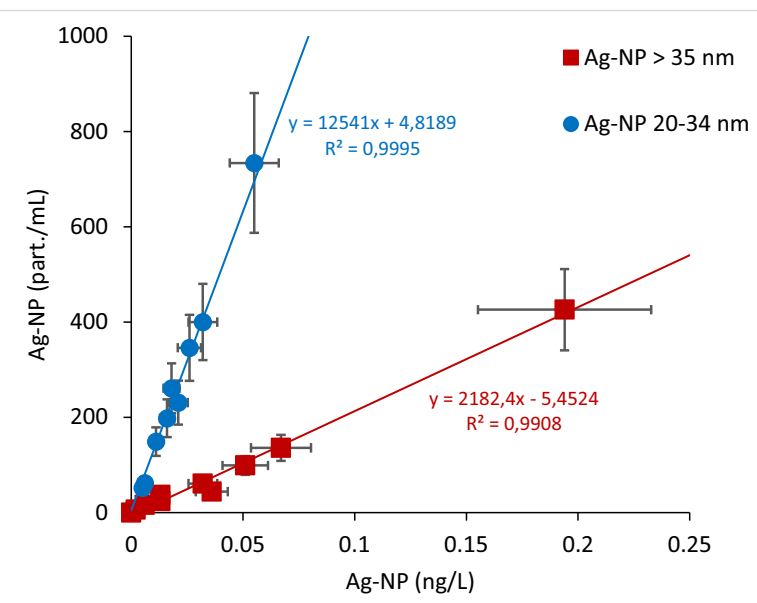

Figure 3 Comparison between Ag NP concentrations expressed as mass $(\mathrm{ng} / \mathrm{L})$ and particle numbers (part $/ \mathrm{mL})$ 
to 3000 particles $/ \mathrm{mL}$ were measured in the small size fraction 20-34 nm, while no more than 450 particles $/ \mathrm{mL}$ in the large NP fraction $(>35 \mathrm{~nm})$. As a general pattern in term of NP size distribution, an average of $730 \%$ enrichment of the small NP fraction was estimated for the investigated wastewater samples. Such information on the relative occurrence of the smallest NP is key for assessing the real impacts of discharged Ag NP. Several studies have shown sizedependent toxic effects. For example, Contreras et al. (2014) found that the small Ag particles ( $2 \mathrm{~nm}$ ) had a notable toxicological effect on nematode while larger particles had different, lower-extent effects. Therefore these studies highlighted the need for size characterization, not just the exposure concentrations, for a better exposure and risk assessment of Ag NP. In standard assessment method development (OECD 2020), such size-based information like particle number concentration (in contrast to mass concentration) is recommended for other exposure metrics that can be used in risk assessments and better understanding the mode of action of different NP forms, i.e., that size, total Ag concentration, and particle density should be included in risk assessment schemes of inorganic NPs.

Acknowledgments We thank S. Teslic from the Environment and Climate Change Canada (ECCC) for his help in sampling. We are also grateful to the WWTP managers and operators for anonymous assistance during sampling and providing WWTP information. We appreciated the feedback and comments from A. Muhametsafina, CMP Nanotechnology.

Authors' contributions C. Gagnon, P. Turcotte, F. Gagné, and SA. Smyth carried out conceptualization and study design. P. Turcotte analysed nanoparticles. S.A Smyth designed and performed sample collection. C. Gagnon, P. Turcotte, F. Gagné, and S.A. Smyth performed manuscript preparation, editing, and revision.

Funding This work was supported by Environment and Climate Change Canada through the Chemical Management Plan.

Data Availability N/A. Data supporting the results reported in the article can be found in the figures and tables included in this paper.

\section{Declarations}

Ethics approval and consent to participate N/A. Human participants, human data, or human tissue were not involved in this study.

Consent to publish N/A. Individual person's data was not involved in this study.

\section{Competing interests The authors declare no conflicts of interest.}

Open Access This article is licensed under a Creative Commons Attribution 4.0 International License, which permits use, sharing, adaptation, distribution and reproduction in any medium or format, as long as you give appropriate credit to the original author(s) and the source, provide a link to the Creative Commons licence, and indicate if changes were made. The images or other third party material in this article are included in the article's Creative Commons licence, unless indicated otherwise in a credit line to the material. If material is not included in the article's Creative Commons licence and your intended use is not permitted by statutory regulation or exceeds the permitted use, you will need to obtain permission directly from the copyright holder. To view a copy of this licence, visit http://creativecommons.org/licenses/by/4.0/.

\section{References}

APHA (2005) Standards methods for the examination of water and wastewater. APHA-AWWA-WEF, Washington

Bhatt I, Tripathi BN (2011) Interaction of engineered nanoparticles with various components of the environment and possible strategies for their risk assessment. Chemosphere 82:308-317

Brar S, Verma M, Tyagi R, Surampalli R (2010) Engineered nanoparticles in wastewater and wastewater sludge - evidence and impacts. Waste Manag 30:504-520

Bruneau A, Turcotte P, Pilote M, Auclair J, Gagné F, Gagnon C (2016) Fate of silver nanoparticles in wastewaters and immunotoxic effects on rainbow trout. Aquat Toxicol 174:70-81

Cervantes-Avilés P, Huang Y, Keller AA (2019) Incidence and persistence of silver nanoparticles throughout the wastewater treatment process. Water Res 156:188-198. https://doi.org/10.1016/j.watres. 2019.03.031

Contreras EQ, Puppala HL, Escalera G, Zhong W, Colvin VL (2014) Size-dependent impacts of silver nanoparticles on the lifespan, fertility, growth, and locomotion of Caenorhabditis elegans. Environ Toxicol Chem 33:2716-2723. https://doi.org/10.1002/etc.2705

Croteau MN, Misra SK, Luoma SN, Valsami-Jones E (2011) Silver bioaccumulation dynamics in a freshwater invertebrate after aqueous and dietary exposures to nanosized and ionic Ag. Environ Sci Technol 45(15):6600-6607

Cunningham S, Brennan-Fournet ME, Ledwith D, Byrnes L, Joshi L (2013) Effect of nanoparticle stabilization and physicochemical properties on exposure outcome: acute toxicity of silver nanoparticle preparations in zebrafish (Danio rerio). Environ Sci Technol 47: 3883-3892. https://doi.org/10.1021/es303695f

Dale AL, Casman EA, Lowry GV, Lead JR, Viparelli E et al (2015) Modeling nanomaterial environmental fate in aquatic systems. Environ Sci Technol 49(5):2587-2593

Degueldre C, Favarger P-Y, Bitea C (2004) Zirconia colloid analysis by single particle inductively coupled plasma-mass spectrometry. Anal Chim Acta 518:137-142

Gagne F, Auclair J, Fortier M, Bruneau A, Fournier M, Turcotte P, Pilote M, Gagnon C (2013) Bioavailability and immunotoxicity of silver nanoparticles to the freshwater mussel Elliptio complanata. J Toxicol Environ Health, Part A: Curr Issues 76(13):767-777. https://doi.org/10.1080/15287394.2013.818602

Gagnon C (2018) Silver nanoparticles in municipal wastewaters and environmental fate. Nano Res Appl 4:53. https://doi.org/10.21767/ 2471-9838-C3-013

Gagnon C, Gagné F, Turcotte P, Saulnier I, Blaise C, Salazar M, Salazar $\mathrm{S}$ (2006) Metal exposure to caged mussels in a primary-treated municipal wastewater plume. Chemosphere 62:998-1010

Georgantzopoulou A, Almeida Carvalho P, Vogelsang C, Tilahun M, Ndungu K, Booth AM, Thomas KV, Macken A (2018) Ecotoxicological effects of transformed silver and titanium dioxide nanoparticles in the effluent from a lab-scale wastewater treatment system. Environ Sci Technol 52(16):9431-9441. https://doi.org/10. 1021/acs.est.8b01663

Gomes T, Araújo O, Pereira R, Almeida AC, Cravo A, Bebianno MJ (2013) Genotoxicity of copper oxide and silver nanoparticles in the mussel Mytilus galloprovincialis. Mar Environ Res 84:51-59 
Government of Canada. (2016) Consultation document: prioritization approach for nanoscale forms of substances on the Domestic Substances List. Health Canada \& Environment and Climate Change Canada. Ottawa. Canada. Web site: www.canada.ca/en/ environment-climate-change/services/canadian-environmentalprotection-act-registry/consultation-document-prioritizationapproach-nanoscale.html\#sl. Accessed 15 Sept 2020

He D, Garg S, Wang Z, Li L, Rong H, Ma X, Li G, An T, Waite TD (2019) Silver sulfide nanoparticles in aqueous environments: formation, transformation and toxicity. Environ Sci: Nano 6:1674-1687

Jiang J, Oberdörster G, Biswas P (2009) Characterization of size, surface charge, and agglomeration state of nanoparticle dispersions for toxicological studies. J Nanopart Res 11:77-89

Johnson AC, Jürgens MD, Lawlor AJ, Cisowska I, Williams RJ (2014) Particulate and colloidal silver in sewage effluent and sludge discharged from British wastewater treatment plants. Chemosphere 112:49-55

Kaegi R, Voegelin A, Sinnet B, Zuleeg S, Hagendorfer H, Burkhardt M, Siegrist H (2011) Behavior of metallic silver nanoparticles in a pilot wastewater treatment plant. Environ Sci Technol 45(9):3902-3908. https://doi.org/10.1021/es1041892

Kaegi R, Voegelin A, Ort C, Sinnet B, Thalmann B, Krismer J, Hagendorfer H, Elumelu M, Mueller E (2013) Fate and transformation of silver nanoparticles in urban wastewater systems. Water Res 47(12):3866-3877

Khan FR, Misra SK, García-Alonso J, Smith BD, Strekopytov S, Rainbow PS, Luoma SN, Valsami-Jones E (2012) Bioaccumulation dynamics and modeling in an estuarine invertebrate following aqueous exposure to nanosized and dissolved silver. Environ Sci Technol 46(14):7621-7628

Kim B, Park C, Murayama M, Hochella MF (2010) Discovery and characterization of silver sulfide nanoparticles in final sewage sludge products. Environ Sci Technol 44:7509-7514

Kim T-H, Kim M, Park H-S, Shin US, Gong M-S, Kim H-W (2012) Sizedependent cellular toxicity of silver nanoparticles. J Biomed Mater Res Part A 100A:1033-1043

Kraas M, Schlich K, Knopf B, Wege F, Kägi R, Terytze K, Hund-Rinke K (2017) Long-term effects of sulfidized silver nanoparticles in sewage sludge on soil microflora. Environ Toxicol Chem 36(12): 3305-3313

Kühr S, Schneider S, Meisterjahn B, Schlich K, Hund-Rinke K, Schlechtriem C (2018) Silver nanoparticles in sewage treatment plant effluents: chronic effects and accumulation of silver in the freshwater amphipod Hyalella azteca. Environ Sci Eur 30:7

Li L, Hartmann G, Döblinger M, Schuster (2013) Quantification of nanoscale silver particles removal and release from municipal wastewater treatment plants in Germany. Environ Sci Technol 47:7317-7323. https://doi.org/10.1021/es3041658

Li L, Stoiber M, Wimmer A, Xu Z, Lindenblatt C, Helmreich B, Schuster M (2016) To what extent can full-scale wastewater treatment plant effluent influence the occurrence of silver-based nanoparticles in surface waters? Environ Sci Technol 50(12):6327-6333. https:// doi.org/10.1021/acs.est.6b00694

Lowry GV, Gregory KB, Apte SC, Lead JR (2012) Transformations of nanomaterials in the environment. Environ Sci Technol 46(13): 6893-6899

Mitrano DM, Lesher EK, Bednar A, Monserud J, Higgins CP, Ranville JF (2012) Detecting nanoparticle silver using single-particle inductively coupled plasma-mass spectrometry. EnvironToxicol Chem $31: 115-121$

Musee N, Thwala M, Nota N (2011) The antibacterial effects of engineered nanomaterials: implications for wastewater treatment plants. J Environ Monit 13(5):1164-1183

OECD (2020) "Guidance document on aquatic and sediment toxicological testing of nanomaterials". Series on Testing and Assessment No. 317. Organisation for Economic Co-operation and Development, Paris. 68 p.

Pace HE, Rogers NJ, Jarolimek C, Coleman VA, Higgins CP et al (2011) Determining transport efficiency for the purpose of counting and sizing nanoparticles via single particle inductively coupled plasma mass spectrometry. Chemosphere 83:9361-9369

Thalmann B, Voegelin A, Sinnet B, Morgenroth E, Kaegi R (2014) Sulfidation kinetics of silver nanoparticles reacted with metal sulfides. Environ Sci Technol 48(9):4885-4892. https://doi.org/10. 1021/es5003378

Tiede K, Boxall ABA, Wang XM, Gore D, Tiede D, Baxter M, David H, Tear SP, Lewis J (2010) Application of hydrodynamic chromatography-ICP-MS to investigate the fate of silver nanoparticles in activated sludge. J Anal At Spectrom 25:1149-1154

Tuoriniemi J, Cornelis G, Hassellöv M (2012) Size discrimination and detection capabilities of single-particle ICP-MS for enviromental analysis of silver nanoparticles. Anal Chem 84:3965-3972

Turcotte P, Gagnon C (2020) Zirconium Interferences on the detection of silver nanoparticles by single particle ICP-MS: implications on natural water analysis. J Nanomed Nanotech 11:550. https://doi.org/10. $35248 / 2157-7439.20 .11 .550$

Publisher's note Springer Nature remains neutral with regard to jurisdictional claims in published maps and institutional affiliations. 